\title{
KNG1 wt Allele
}

National Cancer Institute

\section{Source}

National Cancer Institute. KNG1 wt Allele. NCI Thesaurus. Code C52385.

Human KNG1 wild-type allele is located in the vicinity of $3 q 27$ and is approximately $27 \mathrm{~kb}$ in length. This allele, which encodes kininogen-1 protein, plays a role in the blood coagulation pathway. Mutation or deletion of the wild type allele can result in aberrations in blood coagulation, fibrin clot resolution and inflammatory responses. 